\title{
TURISTIČNI OBISK VISOKOGORJA NA OBMOČJU KAMNIŠKE BISTRICE
}

\author{
dr. Dejan Cigale
}

Oddelek za geografijo, Filozofska fakulteta Univerze v Ljubljani

Aškerčeva 2, SI-I000 Ljubljana

e-mail: dejan.cigale@ff.uni-lj.si

Izvirni znanstveni članek

COBISS 1.01

\section{Izvleček}

V prispevku so obravnavane značilnosti turističnega/prostočasnega obiska visokogorja na primeru gorskih vrhov na območju Kamniške Bistrice ter raznovrstni dejavniki, ki vplivajo nanje. Za preučitev obiska so bili uporabljeni podatki iz vpisnih knjig, ki se nahajajo na vrhovih. Posamezni vrhovi se med sabo močno razlikujejo po številu obiskovalcev, po tem, od kod prihajajo in katero dolino si izbirajo za izhodišče, pa tudi v kolikšni meri so vrhovi obiskani kot samostojni cilji.

Ključne besede: turizem, rekreacija na prostem, visokogorje, gorništvo, dejavniki turističnega obiska

\section{TOURIST VISITS OF HIGH MOUNTAINS IN KAMNIŠKA BISTRICA AREA}

\begin{abstract}
The paper discusses characteristics of tourist/leisure visits of mountain summits in high mountain area of Kamniška Bistrica and various factors that influence them. For the analysis of visits, data from summit books were used. Summits differ in number of visitors, their regional origin and their choice of starting points as well as in the extent to which the visitors are climbing more than one summit during the visit.
\end{abstract}

Key words: tourism, outdoor recreation, high mountain areas, mountaineering, factors of tourist visit 


\section{UVOD}

Turistični obisk se usmerja na raznovrstna območja z zelo raznoliko turistično ponudbo. Pomembnega obiska so deležna tudi gorska območja, med katerimi so po obiskanosti v ospredju Alpe. Največje zgostitve turističnega obiska so običajno na lažje dostopnih dolinskih ali sredogorskih območjih, le del turističnega obiska je usmerjen tudi v visokogorje, ki bi ga lahko opredelili kot "gorski svet, ki s svojimi vrhovi sega nad podnebno zgornjo gozdno mejo« (Geografski terminološki slovar, 2005). Zaradi svojskih naravnogeografskih značilnosti predstavlja specifičen rekreacijski in turistični prostor. V skladu s tem so tudi motivi obiskovalcev pogosto svojevrstni (Loewenstein, 1999). Zaradi raznolikih prostočasnih možnosti, ki jih ponuja gorski svet, so v njem prisotne številne prostočasne dejavnosti (Lorch, 1995; Jeršič, 1999). Nekoliko ožji spekter teh dejavnosti je prisoten v visokogorju, kjer kot prostočasna dejavnost prevladuje planinstvo (glede različnih opredelitev tovrstnih prostočasnih dejavnosti prim. Kristan, 1993; Jeršič, 1999; Planinski terminološki slovar, 2002, idr.), prisotne so tudi nekatere manj množične dejavnosti (alpinizem, jadralno padalstvo, jamarstvo).

Turistični obisk gorskih območij je pomemben tudi v Sloveniji, podatkov o njem pa ni veliko. Po podatkih Statističnega urada Republike Slovenije (v nadaljevanju SURS) za leto 2010 je bilo v gorskih občinah zabeleženih 734.753 prihodov turistov $(24,8 \%$ vseh prihodov v Sloveniji) in 2.018 .990 prenočitev (23,0 \% vseh). O turističnem in rekreacijskem pomenu gorskega sveta v Sloveniji priča tudi dejstvo, da je planinstvo med bolj priljubljenimi prostočasnimi dejavnostmi slovenskega prebivalstva. Tako je bilo po podatkih za leto 2009 planinstvo peta najbolj priljubljena športnorekreativna dejavnost, ki jo je med najbolj priljubljenimi navajalo 14 \% moških in $15 \%$ žensk (Pori, Sila, 2009). Podobno priljubljeno je alpsko smučanje, ki pa je navezano na območja urejenih smučišč.

Na visokogorskih območjih med nastanitvenimi objekti prevladujejo planinske koče in domovi. Po podatkih SURS (za objekte z najmanj 10 ležišči) je bilo v letu $2010 \mathrm{v}$ planinskih domovih zabeleženih 62.326 prihodov turistov $(2,1 \%)$ in 85.419 prenočitev (samo 1,0 \% vseh prenočitev v državi).

Podatki SURS pa le pomanjkljivo zajamejo dejanski obisk gorskih območij, saj so zaradi ugodne dostopnosti deležna tudi velikega enodnevnega obiska, ki ni nikjer registriran. Obstajajo samo podatki o številu obiskovalcev planinskih koč in gorskih vrhov, dobljeni na osnovi vpisov v vpisne knjige. Po podatkih, ki jih navaja Recer (1999), je kar 27 planinskih postojank konec devetdesetih let imelo več kot 22.000 obiskovalcev letno. Največ obiska so zabeležili v nekaterih planinskih postojankah v Julijskih Alpah, zelo obiskana so bila tudi nekatera druga območja, poleg manjših območij Karavank tudi osrednji del Kamniško-Savinjskih Alp.

S turističnim obiskom gorskega sveta povezana vprašanja so bila z različnih vidikov pogosto obravnavana tudi v strokovni literaturi, npr. značilnosti obiska in obiskovalcev (Kariel, 1984), turistični obisk gorskega sveta v kontekstu pustolovskega turizma (Beedie, Hudson, 2003; Pomfret, 2006), vplivi turizma na okolje (Cole, Sinclair, 2002; Heil in sod., 2007), konflikti med različnimi rekreacijskimi dejavnostmi (Benjaminsen, Svarstad, 2008), idr. Razmeroma redko je bila pozornost namenjena 
prvenstveno visokogorju ali dejavnostim, ki se odvijajo v njem (npr. Hanley in sod., 2002; Kuniyal, 2002; Mrak, 2009). Tako ostaja v zvezi s prostočasnim obiskom visokogorja še vrsta odprtih vprašanj, kar velja tudi za Slovenijo. Slabo poznane so tudi številne osnovne značilnosti tovrstnega obiska pri nas, saj ni o njih skoraj nobenih empiričnih podatkov.

Namen pričujočega prispevka je preučitev značilnosti turističnega/prostočasnega obiska visokogorja na območju Kamniške Bistrice, enem najbolj obiskanih gorskih območij v Sloveniji (Cigale, 1998; Recer, 1999), ter dejavnikov, ki vplivajo nanj. Pozornost bo namenjena obisku gorskih vrhov, in sicer:

- Kakšen je velikostni razred obiska posameznih vrhov in kateri so dejavniki, ki vplivajo na razlike v obisku?

- Kakšen je sezonski in tedenski potek obiska?

- Kakšen je vpliv dostopnosti na obisk območja, oziroma izbiro smeri dostopa (izhodišča)?

- V kolikšni meri predstavljajo posamezni vrhovi samostojne cilje obiska in v kolikšni meri prihaja do povezovanja obiska več vrhov?

Slika 1: Obravnavano območje z glavnimi vrhovi in planinskimi postojankami

Figure 1: Area under study with main peaks and mountain huts

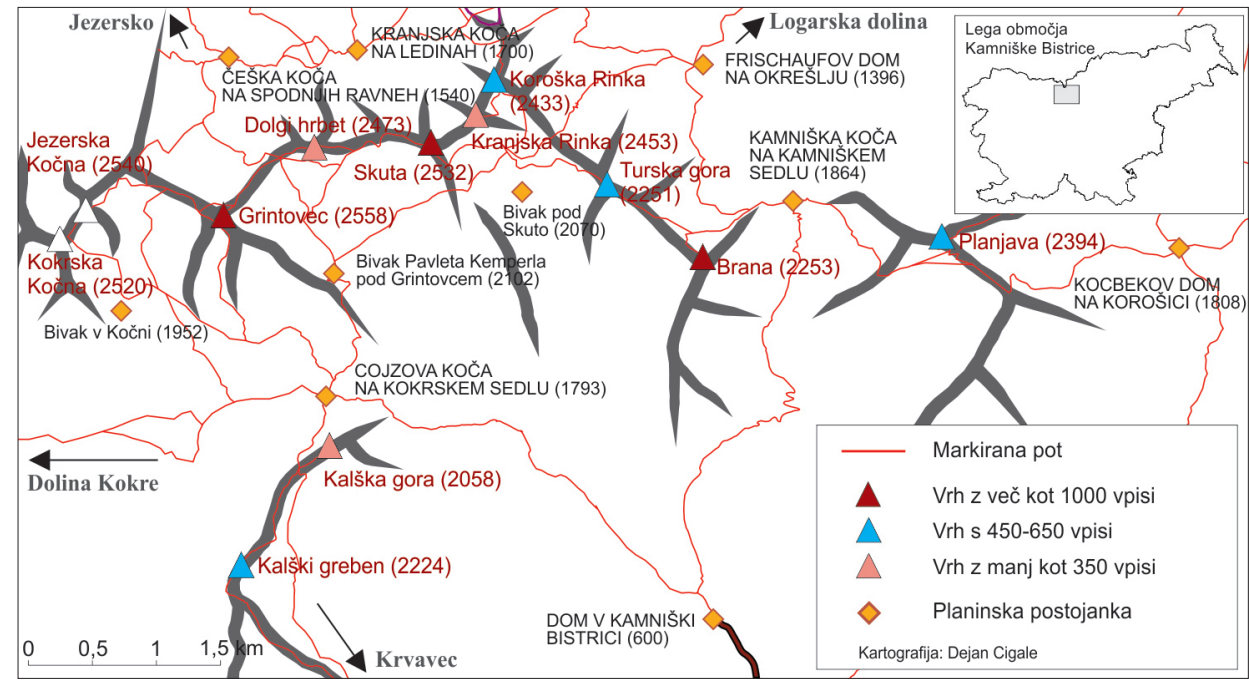

\section{OBRAVNAVANO OBMOČJE}

V prispevku je obravnavano območje Kamniške Bistrice, ki predstavlja eno bolj priljubljenih in iz osrednje Slovenije najlažje dostopnih visokogorskih območij, zaradi česar je deležno precejšnjega obiska. Kolikšen je ta obisk, ni mogoče reči z večjo stopnjo 
zanesljivosti, saj je večinoma v obliki enodnevnih izletov. A tudi podatki o številu prenočitev v Kamniški Bistrici, kakor jih je do leta 2009 po 'pomembnejših turističnih krajih' objavljal SURS, govorijo o precejšnjem obisku.

Prispevek se bo posvetil le obisku visokogorja, oziroma tistih gorskih vrhov, ki so pomembni z vidika planinskega obiska. V obravnavo so bili tako vključeni vrhovi, ki so neposredno dostopni iz Kamniške Bistrice, nanje vodijo markirane poti in presegajo 2000 metrov nadmorske višine. To so: Kalški greben (2224 m), Kalška gora (2058 m), Grintovec (2558 m), Dolgi hrbet (2473 m), Skuta (2532 m), Kranjska Rinka (2453 m), Koroška Rinka ali Križ (2433 m), Turska gora (2251 m), Brana (2253 m) in Planjava (2394 m). Iz Kamniške Bistrice se je mogoče povzpeti tudi na bolj oddaljene Kokrsko in Jezersko Kočno ter Ojstrico, a za to je potreben daljši dostop, zato se zanj odloča razmeroma malo obiskovalcev/ planincev. Podatki o obisku teh treh vrhov niso bili vključeni v analizo.

Dolina Kamniške Bistrice se nahaja na južni strani osrednjega dela Kamniško-Savinjskih Alp. V zgornji del doline je segal v pleistocenu ledenik in jo preoblikoval, opazni so tudi drugi sledovi ledeniškega delovanja, npr. veliki balvani, morenski nasipi ... (Šifrer, 1961). Dolino obdaja večina najvišjih vrhov v gorovju. Pobočja so strma in (v spodnjem delu) v precejšnji meri porasla z gozdom. Dolina je in je bila tudi v preteklosti zelo redko poseljena. Po podatkih SURS je v naselju Kamniška Bistrica sredi leta 2010 živelo samo 23 prebivalcev.

Ena izmed posledic prostočasne privlačnosti območja je prisotnost gostinskih in nastanitvenih objektov. Po podatkih SURS je bilo v Kamniški Bistrici kot 'pomembnejšem turističnem kraju' v poletni sezoni 2009 (julij) na voljo 316 ležišč, od tega 181 v planinskih domovih in kočah, $130 \mathrm{v}$ delavskih počitniških domovih in $5 \mathrm{v}$ 'drugih domovih', vendar je v teh podatkih zajeta tudi bližnja Velika planina. Turistični obisk je znaten in po številu prihodov turistov je bila Kamniška Bistrica v letu 2009 (zadnje leto, za katero so na voljo podatki po 'pomembnejših turističnih krajih') s 3099 prihodi na 63. mestu v Sloveniji. Največji turistični obisk je poleti, nižek pa je spomladi in jeseni, vendar k takšni podobi izrazito prispevajo prenočitve na Veliki planini, ki je zanimiva za množičen obisk tudi v zimskem času.

Preglednica 1: Prihodi in prenočitve turistov v Kamniški Bistrici v letu 2009 po vrstah objektov Table 1: Tourist arrivals and overnight stays in Kamniška Bistrica in 2009 by types of tourist accommodation

\begin{tabular}{|l|c|c|}
\hline & Prihodi & Prenočitve \\
\hline Planinski domovi in koče & 1338 & 1501 \\
\hline Delavski počitniški domovi & 1731 & 4802 \\
\hline Drugi domovi & 30 & 138 \\
\hline Skupaj & $\mathbf{3 0 9 9}$ & $\mathbf{6 4 4 1}$ \\
\hline
\end{tabular}

Vir/Source: Statistični urad RS

Opomba: Zajeti so tudi podatki za Veliko planino. 
Podatki SURS zajemajo tudi Veliko planino, zato so za obravnavano temo bolj zanimivi podatki le za planinske domove. $\mathrm{K}$ dosedaj predstavljenim številkam namreč pomembno prispevajo prenočitve in prihodi v delavskih počitniških domovih, ki so na Veliki planini.

Zgolj v planinskih domovih je bilo v letu 20091338 prihodov in 1501 prenočitev. Daleč največji obisk je bil avgusta (42,2 \% letnih prenočitev) in julija (24,7 \%), sledila sta september in junij. Zunaj tega obdobja je bilo število prenočitev skoraj zanemarljivo. Na takšno stanje vpliva tudi dejstvo, da se planinske koče večinoma odprejo šele junija in zaprejo že oktobra. Sicer je Velika planina zajeta tudi pri podatkih o planinskih domovih, vendar je njen vpliv na skupne številke precej manjši.

Slika 2: Prenočitve v planinskih domovih v 'pomembnejšem turističnem kraju' Kamniška Bistrica leta 2009 po mesecih

Figure 2: Overnight stays in mountain huts in Kamniška Bistrica in 2009 (monthly data)



Vir/Source: Statistični urad RS

Opomba: Zajeti so tudi podatki za Veliko planino.

\section{UPORABLJENI PODATKI IN METODA DELA}

Podatki SURS se nanašajo na širše območje in ne le na visokogorje na območju Kamniške Bistrice, pozornost v prispevku pa naj bi bila namenjena ravno slednjemu. Za preučitev tega obiska (oziroma obiska gorskih vrhov) in njegovih značilnosti si zato nismo mogli veliko pomagati s statističnimi podatki, temveč so bili uporabljeni podatki iz vpisnih knjig, ki se nahajajo na vseh obravnavanih vrhovih. Te vpisne knjige so teoretično na voljo obiskovalcem ves čas, dejansko pa so pozimi pod snegom in zato nedostopne. V pričujočem primeru so bili v analizo vključeni podatki za leto 2010, in sicer za obdobje do konca septembra, ko se zaključi glavna planinska sezona z največ obiska. 
Pri medsebojni primerjavi (in oceni) obiska posameznih vrhov so bili uporabljeni le podatki za obdobje junij-september. Na ta način je bila mogoča bolj zanesljiva primerjava. Podatki za maj so namreč kazali na zelo majhen obisk, tako da bi lahko že prihod ene same skupine pomembno vplival na skupno število vpisov v tem mesecu. Zaradi zamudnosti posameznih analiz so bili v nekatere analize vključeni le podatki za izbrane vrhove. Podatki so bili zbrani v oktobru 2010 neposredno na terenu. Medtem ko na manj obiskanih vrhovih vpisnih knjig ne zamenjajo tudi več let, saj se v eni sezoni ne zapolnijo, jih je potrebno na bolj obiskanih vrhovih menjati večkrat v sezoni. To pomeni, da so bili v takih primerih na voljo krajši podatkovni nizi, ki niso v vseh primerih obsegali celotnega obravnavanega obdobja, ampak le njegov večji ali manjši del. Poleg tega običajno mine kar nekaj časa, preden zamenjajo zapolnjene vpisne knjige. Tako nujno obstajajo v podatkih določene vrzeli.

Razpoložljivi podatki obsegajo datum vpisa, smer prihoda in odhoda ter kraj bivanja, pa tudi podatke o članstvu v planinskem društvu, ki v tem primeru niso bili vključeni v analizo. Omenjeni podatki so omogočili medsebojno primerjavo obsega obiska, oceno približnega velikostnega reda obiska, informacijo o 'vplivnem območju' posameznih vrhov, o izbranem izhodišču, pa tudi o tem, ali je šlo za obisk zgolj ene točke (vrha) ali za kombinacijo vzpona na več vrhov. Ker se vsi obiskovalci ne vpisujejo, so lahko omenjeni podatki služili predvsem kot podlaga za bolj ali manj natančne ocene.

\section{OBSEG OBISKA}

Kot že omenjeno, niso bili v vseh primerih na voljo podatki za celotno obravnavano obdobje. Nepopolni so predvsem podatki za najbolj obiskane vrhove. Za pet vrhov (Kalški greben, Kalška gora, Dolgi hrbet, Kranjska Rinka, Koroška Rinka) so bili na voljo podatki za celotno obdobje, za drugih pet vrhov (Grintovec, Skuta, Turska gora, Brana, Planjava) pa le za različno dolg del obdobja, od manj kot meseca dni (Planjava) do dveh mesecev in pol (Grintovec). Ker so razpoložljivi podatkovni nizi vendarle obsegali razmeroma dolgo obdobje, je bilo mogoče z medsebojno primerjavo podatkov oceniti obisk tudi za vrhove z nepopolnimi podatkovnimi nizi. Pri tem so kot izhodišče služile naslednje domneve:

- Vrhovi so zaradi svojih značilnosti različno privlačni in zato deležni večjega ali manjšega obiska. Mogoče je pričakovati, da je obisk tudi v dneh, za katere ni podatkov, v skladu s to večjo ali manjšo privlačnostjo oziroma priljubljenostjo.

- Na velikostni razred obiska povsod vplivata razporeditev prostega časa (počitnice, prosti konci tedna) in vreme na podoben način (večji obisk ob lepem vremenu ter ob koncih tedna in praznikih). Domnevati je torej mogoče, da je gibanje obiska na vrhovih, za katere so na voljo le nepopolni podatkovni nizi, podobno kot pri vrhovih, za katere so na razpolago popolni podatki. Da so gibanja števila obiskovalcev na vseh vrhovih res zelo podobna, kaže tudi visoka stopnja povezanosti dnevnega števila vpisov na posameznih vrhovih, ki jo je pokazal izračun Spearmanovega koeficienta korelacije za pet vrhov s popolnim podatkovnim nizom (preglednica 2). Vrednosti koeficienta so bile med 0,574 (Kranjska Rinka : Kalška gora) do 0,814 (Dolgi hrbet : Koroška Rinka). To kaže, da na obisk dejansko v veliki meri vplivajo skupni vplivni dejavniki. 
Preglednica 2: Povezanost obiska na obravnavanih vrhovih vobdobju od 1. 6. 2010 do 30. 9. 2010 (vrednosti Spearmanovega koeficienta korelacije)

Table 2: Correlations between visits of various mountain summits in the period between June and September 2010 (values of Spearman's correlation coefficient)

\begin{tabular}{|l|c|c|c|c|c|}
\hline & Kalška gora & Dolgi hrbet & $\begin{array}{c}\text { Kranjska } \\
\text { Rinka }\end{array}$ & Kalški greben & $\begin{array}{c}\text { Koroška } \\
\text { Rinka }\end{array}$ \\
\hline Kalška gora & --- & 0,653 & 0,574 & 0,660 & 0,650 \\
\hline Dolgi hrbet & 0,653 & --- & 0,656 & 0,602 & 0,814 \\
\hline Kranjska Rinka & 0,574 & 0,656 & --- & 0,683 & 0,731 \\
\hline Kalški greben & 0,660 & 0,602 & 0,683 & --- & 0,643 \\
\hline Koroška Rinka & 0,650 & 0,814 & 0,731 & 0,643 & --- \\
\hline
\end{tabular}

Opomba: Vse vrednosti so statistično pomembne na ravni $\alpha=0,01$.

Število vpisov v celotnem obdobju od 1. junija do 30. septembra na vrhovih, za katere je bil na voljo le nepopoln podatkovni niz, je bilo ocenjeno na osnovi primerjave podatkov za vsak posamezen vrh in tistih pet vrhov, za katere so na voljo podatki za celotno obdobje. Pri tem je bila kot izhodišče upoštevana zgoraj navedena domneva, da so zaradi skupnih vplivnih dejavnikov nihanja obiska na vseh vrhovih podobna.

Tako je bilo za vsak dan z manjkajočimi podatki število vpisov za posamezen vrh ocenjeno po naslednji formuli:

$$
V_{g d}=\frac{P D V_{g o}}{P D V_{5 o}} * V_{5 d}
$$

kjer je:

$V_{g d}$ - ocenjeno število vpisov na vrhu g za dan d.

$P D V_{g o}$ - povprečno dnevno število vpisov za vrh g v obdobju o, za katero so bili na razpolago podatki.

$P D V_{5 o}$ - povprečno dnevno število vpisov na 5 vrhovih s popolnim podatkovnim nizom za obdobje o.

$V_{5 d}$ - število vpisov na 5 vrhovih s popolnim podatkovnim nizom za dan $\mathrm{d}$.

Dejansko ali ocenjeno število vpisov je predstavljeno v preglednici 3. Predvsem za Planjavo je ocena števila vpisov v štirimesečnem obdobju manj zanesljiva, saj gre za najkrajši podatkovni niz, a je groba primerjava z drugimi vrhovi vseeno mogoča. Število vpisov v štirimesečenem obdobju sega od več kot 200 do več kot 2000, kar predstavlja desetkratno razliko. Tako ima najbolj obiskan vrh (Grintovec) desetkrat večji obisk kot najmanj obiskana Kranjska Rinka. 
Preglednica 3: Število vpisov v vpisne knjige na vrhovih v obdobju od 1. 6 do 30. 9. 2010 Table 3: Number of entries in summit books in the period between June and September 2010

\begin{tabular}{|l|c|}
\hline Vrh & Število vpisov \\
\hline Grintovec* & 2106 \\
\hline Skuta* & 1104 \\
\hline Brana* & 1057 \\
\hline Turska gora* & 606 \\
\hline Planjava* & 604 \\
\hline Koroška Rinka & 539 \\
\hline Kalški greben & 476 \\
\hline Kalška gora & 327 \\
\hline Dolgi hrbet & 313 \\
\hline Kranjska Rinka & 215 \\
\hline
\end{tabular}

* Ocena

Podatki so pokazali, da lahko glede na obiskanost vrhove razdelimo v tri skupine:

- 1. skupina: najbolj obiskani vrhovi (Grintovec, Skuta, Brana);

- 2. skupina: srednje obiskani vrhovi (Kalški greben, Koroška Rinka, Turska gora, Planjava) s 500-600 vpisov na leto;

- 3. skupina: manj obiskani vrhovi: Kranjska Rinka (najmanj obiskana), Dolgi hrbet in Kalška gora. Tudi na najbolj obiskanem vrhu v tej skupini je število vpisov v štirimesečnem obdobju doseglo le 327.

Za temeljitejšo in bolj sistematično analizo bi bili potrebni podatki za obsežnejše območje, oziroma več območij, kar je zaradi zamudnosti zbiranja in analize tovrstnih podatkov težko izvedljivo. Kljub temu že do sedaj zbrani podatki zadoščajo za nekatere sklepe o dejavnikih, ki vplivajo na večji ali manjši obisk posameznih vrhov.

Najpomembnejši dejavnik je očitno nadmorska višina v kombinaciji z dominantnostjo oziroma višinskim preseganjem bližnjih vrhov (ter posledično obsežnejšim razgledom), saj sta najbolj obiskana oba najvišja vrhova (Grintovec in Skuta). Pri tem je Grintovec po obisku daleč spredaj, kar je verjetno predvsem posledica največje višine. $\mathrm{Na}$ velik obisk vpliva tudi relativno lahka dostopnost (nezahteven dostop z juga), ki pride $\mathrm{v}$ poštev za vse kondicijsko primerno pripravljene obiskovalce. Za razliko od tega vodijo na Skuto le pristopi z zahtevnejšimi odseki poti.

$\mathrm{Na}$ drugi strani so najmanj privlačni tisti vrhovi, ki igrajo glede na svojo višino in lego vlogo sekundarnih vrhov. Tako je npr. Kalška gora (2058 m) manj izrazit vrh v bližini precej višjega Kalškega grebena (2224 m). Podobno velja za Dolgi hrbet (2473 m), ki glede na bližnjo višjo Skuto (2532 m) izgubi na privlačnosti za obiskovalce.

Zdi se, da tudi relativno lažji oziroma krajši peš dostop igra določeno vlogo, saj je na tretjem mestu po obiskanosti Brana, ki je po višini v spodnji polovici obravnavanih 
vrhov, zato pa je relativno hitro in lahko dostopna tako z južne kot severne strani. K velikemu obisku prispeva tudi bližina zelo priljubljenega planinskega doma na Kamniškem sedlu. Vendar pa v obravnavanih primerih zgolj kratek pristop še ni zadosten razlog, ki bi lahko pomembneje vplival na večji obisk (npr. razmeroma hitro dostopna Kalška gora je med najmanj obiskanimi vrhovi). Verjetno $\mathrm{k}$ temu prispeva tudi to, da so tovrstne razlike med obravnavanimi vrhovi razmeroma majhne.

Naslednja dejavnika, na katerih vlogo je mogoče sklepati, sta dostopnost z različnih strani in možnost povezovanja obiska več poti ali ciljev, kar tudi pozitivno vpliva na večji obisk. Tako je npr. Koroška Rinka (2433 m), ki predstavlja vozlišče poti iz treh dolin, precej bolje obiskana kot bližnja, 20 m višja Kranjska Rinka (2453 m). Tudi Turska gora, pri obisku katere je brez večjega truda mogoče povezati pristopa čez Turski žleb in Kamniško sedlo, je kljub dokaj skromni višini dobro obiskana.

Slika 3: Osrednji greben Kamniško-Savinjskih Alp med Grintovcem in Planjavo (v ospredju) (foto: D. Cigale)

Figure 3: Main ridge of the Kamnik-Savinja Alps between Grintovec and Planjava (in the forefront) (Photo: D. Cigale)

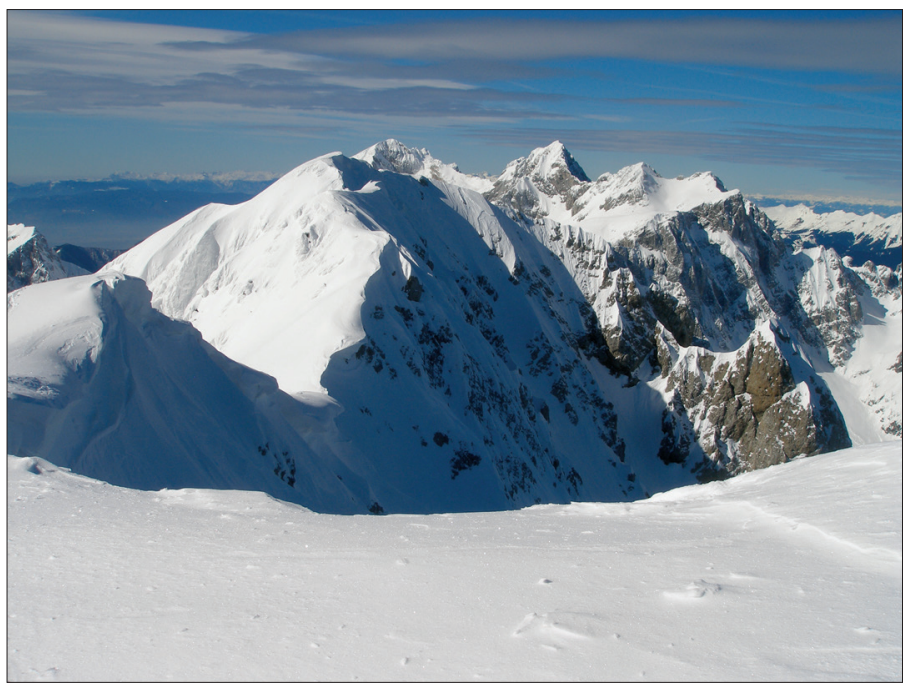

Razmerje med dejanskim obiskom in številom vpisov ostaja odprto vprašanje. Običajno Planinska zveza Slovenije ocenjuje obisk (število obiskovalcev) v planinskih kočah kot trikratnik števila vpisov v vpisno knjigo. Takšno razmerje med vpisi in obiskom bi pomenilo, da bi imel najbolj obiskan vrh Grintovec v štirimesečnem obdobju več kot 6000 obiskovalcev ali v povprečju 52 obiskovalcev dnevno. Da pa bi bilo mogoče takšno številko upoštevati kot dejanski obisk, bi bilo treba empirično ugotoviti dejansko razmerje med številom vpisov in obiskovalcev. Nesistematična in razmeroma kratkotrajna 
lastna opazovanja, ki so sicer pokazala dokaj podobno razmerje, so bila nezadostna. Kljub temu so te številke uporabne vsaj za približno oceno.

Upoštevati je treba tudi dejstvo, da so vrhovi deležni obiska (čeprav manjšega) tudi zunaj poletne sezone, oziroma štirimesečnega obdobja, vendar je obisk takrat precej manjši. Ker so vpisne knjige na vrhovih velik del leta pod snegom, za ugotavljanje obiska $\mathrm{v}$ tem delu leta niso primerne. Za oceno deleža obiska zunaj sezone so bili tako uporabljeni podatki/vpisi iz Bivaka pod Skuto na Malih podih. Tamkajšnja vpisna knjiga je dostopna celo leto, kar pomeni, da vpisi dovolj dobro prikazujejo celoletni potek obiska (preglednica 5). Tako je bilo v dvanajstmesečnem obdobju od novembra 2009 do oktobra 2010 med 1. junijem in 30. septembrom kar 78,4 \% vseh vpisov, v ostalih osmih mesecih pa le $21,6 \%$ vpisov. Potemtakem bi bilo mogoče domnevati, da je bila tudi na obravnavanih vrhovih z obdobjem junij-september zajeta prepričljiva večina obiska.

\section{SEZONSKA IN TEDENSKA RAZPOREDITEV OBISKA}

Na vseh petih vrhovih, za katere so bili na voljo podatki za celotno obdobje do konca septembra 2010, je bil avgust mesec z največjim obiskom pred julijem (preglednica 4), na tretjem mestu pa je bil večinoma september (z izjemo Kalškega grebena, kjer je bilo več vpisov junija), a je po obisku že precej zaostajal za julijem. Maja so se vpisi sicer pojavili na treh od petih vrhov, a je šlo za zelo skromne številke. Delež avgustovskega obiska v petmesečnem obdobju od maja, ko se pojavijo prvi vpisi, do septembra je znašal od 36 do $46 \%$, julijskega pa od 26 do $39 \%$.

Preglednica 4: Deleži vpisov v vpisne knjige na vrhovih (v\%) v letu 2010 po mesecih Table 4: Percentages of entries in summit books by months in 2010

\begin{tabular}{|l|c|c|c|c|c|c|}
\hline Mesec & Maj & Junij & Julij & Avgust & Sept. & Skupaj \\
\hline Kalška gora & 1,2 & 15,4 & 30,8 & 36,3 & 16,3 & 100 \\
\hline Dolgi hrbet & 0 & 8,3 & 32,6 & 41,9 & 17,3 & 100 \\
\hline Kranjska Rinka & 1,4 & 8,3 & 28,9 & 45,9 & 15,6 & 100 \\
\hline Kalški greben & 1,2 & 18,7 & 25,9 & 36,1 & 18,0 & 100 \\
\hline Koroška Rinka & 0 & 3,9 & 39,0 & 42,9 & 14,3 & 100 \\
\hline Skupaj & $\mathbf{0 , 7}$ & $\mathbf{1 0 , 9}$ & $\mathbf{3 2 , 0}$ & $\mathbf{4 0 , 1}$ & $\mathbf{1 6 , 3}$ & $\mathbf{1 0 0}$ \\
\hline
\end{tabular}

Opomba: Upoštevani so le vrhovi, za katere so na voljo podatki od začetka sezone do konca septembra 2010.

Opozoriti je treba na odsotnost podatkov za oktober, ko je lahko v primeru lepega vremena planinski obisk še znaten. Podatki so bili namreč pridobljeni tekom oktobra, zato za ta mesec niso bili na voljo, vendar je bil obisk v visokogorju oktobra že zmanjšan zaradi novozapadlega snega. O razmeroma zelo majhnem izpadu vpisov po koncu septembra pričajo tudi naknadno zbrani podatki za Kalški greben in Kalško goro, ki sta 
do konca leta 2010 (v oktobru in novembru) zabeležila le še 44 oziroma 34 vpisov, kar predstavlja 9,2 \% oziroma 10,4\% celotnega letnega števila vpisov.

Na precej manjši obisk po koncu septembra in zunaj poletne sezone nasploh kažejo tudi že omenjeni podatki za Bivak pod Skuto. Kljub razmeroma majhnemu številu vpisov je razviden podoben potek obiska kot na vrhovih. Največji obisk je bil avgusta, pred julijem in septembrom, sledil pa je junij.

Preglednica 5: Število in delež vpisov po mesecih v Bivaku pod Skuto v obdobju november 2009 - oktober 2010

Table 5: Number and percentage of entries by months in bivouac below Skuta for the period November 2009 - October 2010

\begin{tabular}{|l|c|c|}
\hline Mesec & Število & Delež (\%) \\
\hline November & 23 & 8,0 \\
\hline December & 1 & 0,3 \\
\hline Januar & 5 & 1,7 \\
\hline Februar & 0 & 0,0 \\
\hline Marec & 4 & 1,4 \\
\hline April & 4 & 1,4 \\
\hline Maj & 0 & 0,0 \\
\hline Junij & 28 & 9,8 \\
\hline Julij & 56 & 19,5 \\
\hline Avgust & 96 & 33,4 \\
\hline September & 45 & 15,7 \\
\hline Oktober & 25 & 8,7 \\
\hline Skupaj & $\mathbf{2 8 7}$ & $\mathbf{1 0 0 , 0}$ \\
\hline
\end{tabular}

Precejšnje razlike v obisku je bilo mogoče pričakovati tudi v obsegu obiska med tednom in ob koncih tedna, na kar vplivajo razlike v razpoložljivem prostem času. Podatki so takšna predvidevanja potrdili. Ne samo, da je bil na povprečen dan ob koncu tedna obisk precej večji kot na povprečen dan med tednom, ampak je predstavljala vsota vpisov ob koncih tedna praviloma več kot polovico vseh. Podatki za pet vrhov s popolnim podatkovnim nizom pokažejo, da je bil delež vpisov ob koncu tedna med 51,4 \% (Dolgi hrbet) in $61,2 \%$ (Kalška gora). Potemtakem je bila v $29 \%$ dni, ki so jih predstavljali dnevi ob koncu tedna in drugi dela prosti dnevi (prazniki), zabeležena večina vpisov, kar zelo nazorno kaže na koncentracijo obiska ob koncih tedna tudi v visokogorju. Prevlada obiskov gora ob koncu tedna se sicer spreminja prek leta in je najmanjša na višku planinske sezone, tj. avgusta, ko lahko zaradi dopustov več ljudi obišče gore tudi med tednom, a tudi tedaj skupni obisk vseh petih vrhov ob koncu tedna še zmeraj preseže $50 \%$. 


\section{SMERI DOSTOPA IN KRAJ BIVANJA}

Obravnavano območje je deležno obiska iz različnih smeri, oziroma iz različnih dolin. Za najgosteje poseljeno območje osrednje Slovenije (širše območje Ljubljane) je Kamniška Bistrica najbližje izhodišče, zato bi bilo mogoče pričakovati, da bo prevladoval obisk iz te smeri. Na drugi strani pa za obsežno območje severovzhodne Slovenije ponuja Zgornja Savinjska dolina najhitrejši dostop do Kamniško-Savinjskih Alp, ki so tudi najbližje visokogorsko območje, medtem ko so iz osrednje Slovenije tudi Julijske Alpe razmeroma hitro dostopne.

Med podatki v vpisnih knjigah je tudi smer dostopa. Slednje obiskovalci razumejo na različne načine. Nekateri v vpisnih knjigah navajajo dolinska izhodišča, drugi zadnjo točko (planinska koča, drug vrh, sedlo), ki so jo obiskali pred obiskom določenega vrha, oziroma pred vpisom v vpisno knjigo. Zaradi tega je mogoče ugotoviti izhodiščno dolino le za del primerov, dela vpisov pa s tega vidika ni mogoče interpretirati. Za ugotavljanje, od kod (iz katere doline) prihajajo obiskovalci, so bili uporabljeni vsi vpisi, iz katerih je bila razvidna dolina izhodišča. Zaradi zamudnosti tovrstne analize je bila izvedena le za štiri vrhove, in sicer Koroške Rinke, Dolgega hrbta, Brane in Kalškega grebena. Izbrani so bili vrhovi, ki se med sabo razlikujejo glede na možne smeri dostopa, oziroma izhodišča. Upoštevani so bili vsi razpoložljivi podatki za leto 2010. Rezultati analize so predstavljeni v nadaljevanju.

Kalški greben: Le $10 \%$ obiskovalcev Kalškega grebena pride iz doline Kamniške Bistrice, slaba četrtina (24 \%) iz doline Kokre, dve tretjini (66 \%) z območja Krvavca. Potemtakem sodi Kalški greben le v manjši meri v rekreacijski prostor Kamniške Bistrice. Vzrok, da največ obiskovalcev pride z območja Krvavca, je nedvomno najlažji in najkrajši dostop. Obiskovalci lahko s hojo začnejo na razmeroma veliki nadmorski višini, po želji se lahko tudi izognejo zahtevnejšim potem. Izhodišča v dolini Kamniške Bistrice in Kokre so precej niže (npr. v dolini Kamniške Bistrice okoli 900 m ob koncu makadamske ceste, pri planinskem domu le $600 \mathrm{~m}$ ), tudi pot je zahtevnejša.

Brana: Na Brano prihajajo obiskovalci tako iz doline Kamniške Bistrice kot iz Logarske doline. Vpisov iz Logarske doline je nekoliko več, relativno največ obiskovalcev pa kot smer dostopa navaja Kamniško sedlo. Zaradi slabe dostopnosti obeh dolin z javnim prometom večina obiskovalcev uporablja isto dolino za dostop in sestop. Zato je pri obiskovalcih, ki so kot smer prihoda navajali Kamniško sedlo, mogoče domnevati, da so za sestop izbrali isto dolino kot za dostop. Ker med njimi prevladuje kot smer sestopa Logarska dolina (razmerje med Logarsko dolino in Kamniško Bistrico je približno 2 : 1), je mogoče sklepati, da je takšen tudi delež Logarske doline kot izhodišča. Delež obiskovalcev iz Logarske doline znaša 59 \%, delež tistih, ki pridejo iz doline Kamniške Bistrice, pa $41 \%$.

Dolgi hrbet: Zaradi razmeroma skromnega deleža izrecnih navedb izhodišča $\mathrm{v}$ eni ali drugi dolini so bili za oceno zastopanosti posameznih dolin kot izhodišč vzponov uporabljeni tudi vpisi, pri katerih je navedba smeri odhoda omogočala dovolj zanesljivo sklepanje o smeri dostopa. Tako je bilo mogoče oceniti, da je prišlo na Dolgi hrbet okrog 27 \% obiskovalcev iz Kamniške Bistrice, 73 \% pa z Jezerskega. Takšno razmerje lahko 
pripišemo hitrejšemu in bolj neposrednemu pristopu s severa. Poleg tega je s severne strani Dolgi hrbet videti precej bolj izrazita gora kot z južne. Iz Kamniške Bistrice je vrh tudi manj direktno dostopen, vsaj po markiranih planinskih poteh, zato sta dostop in sestop daljša.

Koroška Rinka: Koroška Rinka je zaradi svoje lege dostopna iz treh dolin: z Jezerskega, iz Logarske doline in iz Kamniške Bistrice. Dostop z Jezerskega in Logarske doline je krajši in bolj neposreden kot iz Kamniške Bistrice. Pot od severa je sicer zahtevna, a markirana. Markirani dostopi iz kamniškobistriške strani so dolgotrajni, saj vodijo s Kokrskega ali Kamniškega sedla. Nemarkirani pristopi so nekoliko zahtevnejši in jih obiskovalci uporabljajo manj pogosto. Podatki kažejo, da pride na Koroško Rinko polovica obiskovalcev (50 \%) s savinjske strani, dobre štiri desetine (43\%) z jezerske strani in manj kot desetina (7 \%) iz Kamniške Bistrice.

Potemtakem se pri nobenem izmed vrhov, za katere so bili analizirani podatki, ni pokazala vodilna vloga Kamniške Bistrice kot izhodišča, temveč so prednjačili dostopi z drugih strani. Na to bi lahko vplivalo več dejavnikov, o katerih bi si bilo mogoče ustvariti boljšo sliko, če bi upoštevali tudi kraj bivanja obiskovalcev. Eno izmed vprašanj o dejavnikih, ki vplivajo na izbor izhodišča vzpona, je namreč tudi, ali posamezniki izbirajo izhodišče prvenstveno v skladu z oddaljenostjo od kraja bivanja. Za razjasnitev tega vprašanja so bili dodatno analizirani podatki o kraju bivanja obiskovalcev za dva izbrana vrhova, in sicer za Brano in Kalški greben. Kraja bivanja sicer ni bilo mogoče razbrati za vse vpisane obiskovalce (ni bil naveden ali obstaja več naselij z enakim imenom), tako da so v nadaljevanju predstavljene številke le okvirne, saj smo upoštevali le vpise, pri katerih je bilo kraj bivanja mogoče ugotoviti.

Med obiskovalci Brane jih je bilo 41 \% s širšega ljubljanskega območja (Osrednjeslovenska statistična regija), 37 \% iz severovzhodne Slovenije (Koroška, Savinjska, Podravska in Pomurska regija). Ostala območja Slovenije in tujina so zastopani le v manjši meri. Primerjava s podatki o izbranem izhodišču pokaže precejšen vpliv bližine oziroma dostopnosti, ki pa ni edini ali izrazito prevladujoč. Na to opozarja dejstvo, da jih med tistimi, ki so prišli iz Logarske doline, 10 \% biva na širšem ljubljanskem območju. Na drugi strani jih je bilo med tistimi, ki so se povzpeli na vrh iz Kamniške Bistrice, $5 \%$ iz severovzhodne Slovenije. To pomeni, da se je v obeh primerih del obiskovalcev odločil za bolj oddaljeno izhodišče.

Velika večina obiskovalcev Kalškega grebena prihaja ali iz Osrednjeslovenske (45 \%) ali iz Gorenjske statistične regije (31\%). Od tistih, ki so prišli na Kalški greben iz doline Kamniške Bistrice, jih je bilo le 8 \% doma na območju Gorenjske, vsi ostali v Osrednjeslovenski regiji (42\%), na drugih območjih Slovenije ali v tujini. Med obiskovalci iz doline Kokre je razmerje med prebivalci Osrednjeslovenske in Gorenjske statistične regije približno $1: 1,5$. Med obiskovalci, ki so prišli s krvavške strani, pa je razmerje med obema območjema obratno (približno 1,5 : 1 v korist obiskovalcev z ljubljanskega območja).

Rezultati kažejo, da je vpliv dostopnosti pri izbiri izhodišča zelo pomemben, nikakor pa ni edini. Za velik del obiskovalcev je pri izbiri izhodišča pomembno, kako visoko je mogoče priti z avtom. Višje izhodišče pomeni krajši, hitrejši in manj naporen dostop, tudi če vključuje daljšo vožnjo. Tako ima pri številnih vrhovih Jezersko prednost pred 
Kamniško Bistrico zaradi nekoliko višjih izhodišč in bolj neposrednih (ter na ta način časovno krajših) dostopov. V primeru Kalškega grebena je še toliko bolj izrazita tovrstna prednost Krvavca.

Tudi naslednji dejavnik je posredno povezan z dostopnostjo. V času, ki je za velik del obiskovalcev še sprejemljiv, je namreč za prebivalce iz osrednje Slovenije dostopen tudi velik del Julijskih Alp. Potemtakem lahko obiskovalci z ljubljanskega območja izbirajo med več cilji in se zato nekoliko manj množično odpravljajo na to območje. Za prebivalce številnih območij severovzhodne Slovenije pa predstavlja Zgornja Savinjska dolina izrazito najkrajši dostop do visokogorja, kar vpliva na njihov večji obisk.

Nezanemarljiv del obiskovalcev si izbira izhodišče tudi na osnovi drugih kriterijev. Mednje bi sodila pokrajinska privlačnost, želja po obisku novih območij ali poti, želja po občasni spremembi, idr. Njihov resničen pomen bi lahko pojasnili šele z anketiranjem obiskovalcev.

\section{POVEZAVA OBISKA VEČ VRHOV}

Turistični obisk posameznih območij je odvisen od različnih dejavnikov. Smith (1983) navaja kot ključne dejavnike privlačnost, razdaljo in velikost trga. Na privlačnost spet delujejo zelo različni dejavniki (Priskin, 2001; Dramstad in sod., 2006). Nekateri so pomembni le za večdnevni obisk (npr. kakovost prenočišč), drugi pa tudi v povezavi z enodnevnimi prostočasnimi potovanji. V primeru planinstva je treba upoštevati posebne motive obiskovalcev. Dejavnik, ki lahko stopnjuje privlačnost obiska določenega območja, je tudi možnost povezave obiska več turističnih/prostočasnih ciljev. Raziskave turističnega obiska so pokazale, da povezavo več ciljev v okviru enega turističnega potovanja (multidestinacijska potovanja) pogojuje več dejavnikov, npr. iskanje mnogovrstnih koristi, heterogenost preferenc posameznikov, zmanjševanje tveganja in negotovosti, ekonomski racionalizem, prostorske značilnosti destinacij in drugi (Tideswell, Faulkner, 1999). V obravnavanem primeru gre za zelo poseben primer turističnega obiska, saj prevladuje enodnevni obisk, motivi za obisk in tudi poglavitni vplivni dejavniki obiska pa so zelo specifični. Ne glede na to je vprašanje povezave več ciljev vredno pozornosti, saj je bilo opaženo kot verjetni dejavnik, ki vpliva na večji obisk.

Za ugotovitev tovrstnih značilnosti so bili analizirani podatki za štiri vrhove (Brana, Turska gora, Kranjska Rinka in Skuta), ki so bili izbrani zaradi ustreznega podatkovnega niza (dovolj velik obseg podatkov in dovolj veliko število navedb, ki jih je bilo mogoče uporabiti za pričujoči namen) ter prostorske bližine, ki je olajšala primerjavo. V preglednici 7 so za omenjene vrhove navedeni deleži tistih vpisov, ki so omenjali obisk vsaj še enega dodatnega vrha. Z visoko stopnjo zanesljivosti je mogoče pričakovati, da so v resnici deleži še nekoliko višji, saj je lahko npr. obiskovalec Skute spotoma obiskal še Dolgi hrbet, čeprav je kot smer dostopa navedel Češko kočo ali pa je obiskovalec Turske gore, ki je navedel kot smer dostopa Kamniško sedlo, spotoma obiskal še Brano. Tako so navedeni odstotni deleži spodnja meja deleža tistih obiskovalcev, ki so obiskali vsaj dva vrhova. 
Preglednica 7: Deleži obiskovalcev, ki so obiskali več kot en vrh Table 7: Percentages of visitors who visited more than one summit

\begin{tabular}{|l|c|}
\hline Vrh & Delež (\%) \\
\hline Brana & 10,9 \\
\hline Turska gora & 26,5 \\
\hline Skuta & 36,8 \\
\hline Kranjska Rinka & 73,1 \\
\hline
\end{tabular}

Podatki kažejo na velike razlike med vrhovi. Sklepati je mogoče, da je pri tem glavni dejavnik predvsem enostavnost obiska dodatnega vrha (ne prevelika poraba časa in energije), pa tudi 'vrednost' vrha kot samostojnega cilja. Izmed štirih obravnavanih primerov sta tako skrajnosti Brana in Kranjska Rinka. V prvem primeru gre za goro, ki deluje kot izrazit, samostojen vrh tako s savinjske kot kamniškobistriške strani. Vrh je dobro ločen od drugih, saj so Kotliči (škrbina na zahodni strani) približno 300 m nižji, Kamniško sedlo na vzhodu pa okrog $350 \mathrm{~m}$. Zatorej zahteva obisk kateregakoli dodatnega vrha precejšnjo dodatno višinsko razliko. Na drugi strani je Kranjska Rinka le eden izmed številnih vrhov, ki se dvigajo nad Malimi podi oziroma nad Jezerskim. Po višini jo izrazito prekaša bližnja Skuta, zato za nekatere obiskovalce verjetno predstavlja le drugorazredni cilj. Poleg tega je mogoče kombinirati obisk njenega vrha z obiskom sosednjih vrhov (zlasti Koroške Rinke), z le malo dodatne višinske razlike.

\section{SKLEP}

Prispevek obravnava planinski obisk visokogorja, ki predstavlja pomemben cilj prostočasnih potovanj. Kljub razmeroma majhnemu obsegu obravnavanega območja so se pokazale velike razlike glede nekaterih značilnosti turističnega obiska. Tako se posamezni vrhovi med sabo močno razlikujejo po obsegu obiska, po tem, od kod prihajajo obiskovalci in katero dolino si izbirajo za izhodišče, pa tudi glede tega, v kolikšni meri so obiskovani kot samostojni cilji. Skupna sta jim sezonska in tedenska razporeditev obiska.

Rezultati kažejo, da je glavni dejavnik števila obiskovalcev privlačnost, ki jo za obiskovalce predstavlja nadmorska višina, zlasti v povezavi z višinskim preseganjem okoliških vrhov. Upoštevanja vredno vlogo igrata tudi možnost povezav različnih poti in ciljev ter dostopnost (tako z vidika za hojo potrebnega časa kot težavnosti poti). Slednja se pokaže kot pomemben dejavnik šele v drugi vrsti, kar je tudi posledica dejstva, da med obravnavanimi vrhovi glede tega ni zelo velikih razlik. Analiza kakšnega drugega, bolj heterogenega območja, bi verjetno opozorila še na pomen drugih dejavnikov, npr. bližine planinske koče, ki v obravnavanem primeru ni bistveno različna med vrhovi.

Razdalja med krajem bivanja in ciljnim območjem ter časovna dostopnost vplivata na regionalni izvor obiskovalcev posameznih vrhov, a pri izbiri določenega 
prostočasnega cilja igra pomembno vlogo tudi prisotnost drugih enakovrednih (ali še privlačnejših) ciljev v ne preveliki oddaljenosti. Razmeroma visok delež obiskovalcev Kamniško-Savinjskih Alp iz severovzhodne Slovenije posredno kaže, da se velik del prebivalcev osrednje Slovenije odloča za obisk sicer nekoliko bolj oddaljenih, a za številne obiskovalce tudi bolj privlačnih Julijskih Alp (večja izbira možnih ciljev, večje nadmorske višine, idr.).

Številni vrhovi nad Kamniško Bistrico so v večji meri del drugih rekreacijskih območij, saj jih obiskovalci obiskujejo predvsem iz drugih dolin. Na izbiro izhodiščne doline v veliki meri vpliva njena bližina glede na kraj bivanja, vendar so za nezanemarljiv del obiskovalcev pomembni tudi drugi razlogi, povezani tako z manj naporno hojo iz določenega izhodišča, kot tudi z željo po novem, ali z večjo privlačnostjo določenega območja. To govori o vrednotenju ciljev s strani potencialnih obiskovalcev, ki ne vključuje zgolj ‘ekonomskih' dejavnikov (npr. večja poraba časa in večji stroški, povezani z izbiro bolj oddaljenih izhodišč), temveč tudi tiste, ki so povezani s kakovostjo prostočasnega doživetja in ki lahko odtehtajo morebitne večje stroške in daljšo pot.

Nekateri vrhovi nastopajo predvsem kot samostojni cilji, drugi so obiskani predvsem v okviru pohodov, ki vključujejo obisk več vrhov ali drugih gorniških ciljev. Slednje povečuje kakovost prostočasnega doživetja obiskovalcev (gornikov). Na povezovanje obiska več vrhov vplivajo tudi različni drugi dejavniki. Zdi se, da pri tem igrajo najpomembnejšo vlogo obstoječe možnosti (bližina drugih vrhovov, prisotnost več poti, ki omogočajo kombinacije različnih dostopov in sestopov). Za razliko od oblik turizma, ki ne vključujejo bolj naporne fizične aktivnosti, je namreč v primeru planinstva pri kombiniranju več ciljev v okviru enega turističnega potovanja (planinskega vzpona) lahko ključna ovira tudi (pre)velika fizična zahtevnost obiska dodatnih ciljev, kar je še zlasti pomembno v okviru prevladujočih enodnevnih izletov.

Predstavljene ugotovitve kažejo na precej zapletene prostorske značilnoste prostočasne, oziroma rekreacijske rabe visokogorskega sveta. Zaradi omejene količine analiziranih podatkov so posplošitve težje oziroma manj zanesljive, vseeno pa uporabljeni podatki nazorno pričajo o osnovnih značilnostih obiska visokogorja ter opozarjajo na nekatere dejavnike, ki igrajo pri tem pomembno vlogo. Kljub bližini se lahko sosednji vrhovi pomembno razlikujejo glede izvora in usmerjenosti 'turističnih' tokov, medsebojnih povezav in drugih lastnosti. Poznavanje značilnosti obiska in dejavnikov, ki vplivajo nanj, ni pomembno samo zaradi boljšega razumevanja tovrstne, specifične oblike turističnega obiska, temveč tudi z vidika zagotavljanja ustreznih prostočasnih možnosti (prosti čas kot sestavina kakovosti življenja) ter preučevanja raznovrstnih učinkov tega obiska.

Prispevek še zmeraj pušča precej odprtih vprašanj. O pomenu nekaterih dejavnikov, ki vplivajo na obisk vrhov in njegove značilnosti, je bilo mogoče zgolj sklepati, dodatno preučevanje pa bi najbrž opozorilo še na vlogo drugih dejavnikov, ki jih pričujoča raziskava ni mogla zajeti. Glede na pomen prostočasnega obiskovanja visokogorja za številne prebivalce Slovenije in turiste, bi bile vsekakor dobrodošle nadaljnje, bolj poglobljene raziskave, ki bi lahko podrobneje osvetlile nekatera neodgovorjena vprašanja in potrdile ali relativizirale dobljene ugotovitve. 


\section{Viri in literatura}

Beedie, P., Hudson, S., 2003. Emergence of mountain-based adventure tourism. Annals of tourism research, 30, 3, str. 625-643. New York.

Benjaminsen, T. A., Svarstad, H., 2008. Understanding traditionalist opposition to modernization: narrative production in a Norwegian mountain conflict. Geografiska annaler, series B (Human geography), 90, 1, str. 49-62. Oxford.

Cigale, D., 1998. Bližnja rekreacija prebivalstva malih mest in njeni pokrajinski učinki (na primeru Domžal). Magistrsko delo. Ljubljana, Filozofska fakulteta, Oddelek za geografijo, 248 str.

Cole, V., Sinclair, A. J., 2002. Measuring the ecological footprint of a Himalayan tourist center. Mountain research and development, 22, 2, str. 132-141. Tokyo, Bern.

Dramstad, W. E., Sundli Tveit, M., Fjellstad, W. J., Fry, G. L. A., 2006. Relationships between visual landscape preferences and map-based indicators of landscape structure. Landscape and urban planning, 78, 4, str. 465-474. Amsterdam.

Geografski terminološki slovar. 2005. Ljubljana, Založba ZRC, 451 str.

Hanley, N., Alvarez-Farizo, B., Shaw, W. D., 2002. Rationing an open-access resource: mountaineering in Scotland. Land use policy, 19, 2, str. 167-176. Guildford.

Heil, L., Fernández-Juricic, E., Renison, D., Cingolani, A. M., Blumstein, D. T., 2007. Avian responses to tourism in the biogeographically isolated high Córdoba Mountains, Argentina. Biodiversity and conservation, 16, 4, str. 1009-1026. London.

Jeršič, M., 1999. Prostorsko planiranje rekreacije na prostem. Ljubljana, Ministrstvo za okolje in prostor, Urad RS za prostorsko planiranje, $135 \mathrm{str}$.

Kariel, H. G., 1984. Tourism in the Canadian Cordillera: a synthesis of visitor characteristics and areal use patterns. Mountain research and development, 4, 3, str. 213-228. Bern.

Kristan, S., 1993. V gore: izletništvo, pohodništvo, gorništvo. Radovljica, Didakta, 274 str.

Kuniyal, J. C., 2002. Mountain expeditions: minimising the impact. Environmental impact assessment review, 22, 6, str. 561-581. New York.

Loewenstein, G., 1999. Because it is there: the challenge of mountaineering ... for utility theory. Kyklos, 52, 3, str. 315-343. Basel.

Lorch, J., 1995. Trendsportarten in den Alpen: Konflikte, rechtliche Reglementierungen, Lösungen. Vaduz, Internationale Alpenschutzkommission CIPRA, 128 str.

Mrak, I., 2009. Sonaravni razvoj turizma in rekreacije v visokogorju. Doktorsko delo. Ljubljana, Filozofska fakulteta, Oddelek za geografijo, 203 str.

Nepal, S. K., Chipeniuk, R., 2005. Mountain tourism: toward a conceptual framework. Tourism geographies, 7, 3, str. 313-333. London.

Planinski terminološki slovar. 2002. Ljubljana, Založba ZRC, 455 str.

Pomfret, G., 2006. Mountaineering adventure tourists: a conceptual framework for research. Tourism management, 27, 1, str. 113-123. New York.

Pori, M., Sila, B., 2009. Kaj nam je najbolj všeč? Polet: magazin Dela in Slovenskih novic, 8, 23 (11. 6. 2009). Ljubljana. 
Priskin, J., 2001. Assessment of natural resources for nature-based tourism: the case of the Central Coast region of Western Australia. Tourism management, 22, 6, str. 637-648. New York.

Seznam koč. Planinska zveza Slovenije. URL: http://www.pzs.si/index. php?stran=Seznam\%20koč (Citirano 24. 8. 2011).

Recer, Š., 1999. Načrtovanje planinstva in pohodništva v slovenskem visokogorju. Diplomsko delo. Ljubljana, Biotehniška fakulteta, Oddelek za krajinsko arhitekturo, 133 str.

Smith, S., 1983. Recreation geography. London, New York, Longman, 220 str.

Šifrer, M., 1961. Porečje Kamniške Bistrice v pleistocenu. Ljubljana, Slovenska akademija znanosti in umetnosti, 211 str.

Tideswell, C., Faulkner, B., 1999. Multidestination travel patterns of international visitors to Queensland. Journal of travel research, 37, 4, str. 364-374. Boulder.

\section{TOURIST VISITS OF HIGH MOUNTAINS IN KAMNIŠKA BISTRICA AREA}

\section{Summary}

Mountain areas are popular tourist destinations but, usually only a smaller part of tourist flows is directed to high mountain areas above forest line, where mountaineering is the most important recreation activity. In this paper, tourist visits of mountain summits in Kamniška Bistrica area is discussed. The area is located in northern Slovenia, on the southern side of the main ridge of Kamnik-Savinja Alps. It is an important recreation and tourism destination. The paper focuses on the visits of those mountain summits, which exceed 2000 meters and are accessible by marked paths.

For the analysis of the visit characteristics, summit registers were used. Data (summit book entries) for the year 2010, more precisely from the beginning of the mountaineering season till the end of September 2010, were included in the analysis. With the end of September, the main mountaineering season is over and number of visitors usually diminishes. Data were collected during October 2010.

Despite rather small size of the area under study, important differences in visit characteristics were found. Summits differ in numbers of visitors, visitors' origin, their choice of starting point, and in extent to which they are visited as independent 'destinations' or as a part of 'multidestination' hiking trips. On the other hand, because of the influence of weather and distribution of free time, they have in common the seasonal and weekly distribution of visitor numbers.

The most important factor, which influences the number of visitors seems to be summit's elevation and its dominance over neighboring summits. To this, also extensive panoramas are related. An important role is played also by the possibility of including more than one peak in a hiking itinerary and by summit's accessibility (time required for reaching a summit as well as difficulty of the trail). The latter is only of secondary importance what is probably a consequence of the fact that, among the peaks under study, these differences are not very significant. Data from other, more heterogeneous area 
would probably point out some other factors, e.g. vicinity of mountain huts, what is not a factor of differentiation for Kamniška Bistrica area.

Distance between the place of living and destination area and, consequently, time necessary for the journey influence the regional origin of visitors to specific peak, but for the selection of destination area an important factor is also the presence of other equally (or more) attractive destinations.

Many peaks in Kamniška Bistrica area are to a larger extent part of other recreation areas, because most of visitors approach them from other valleys. While the choice of the starting point is - to a large extent - influenced by the proximity to the place of living, for the important part of visitors other factors are also of importance, e.g. efforts needed to climb a peak, attractivity of an area, its novelty (many visitors tend to seek variety, to visit new destinations), etc. This shows that visitors'/mountaineers' evaluation of hiking destinations is not based only on economic criteria (e.g. costs related to distance and time traveled) but also on the ones related to the quality of recreation experience, which can compensate eventual higher costs and distance traveled.

Some peaks are visited mainly on trips involving visit to only one summit, while others are visited primarily on trips, which include visits to more than one summit or other hiking destination. Such 'multidestination' hikes/trips enhance the quality of visitors' leisure experience. Inclusion of more than one destination (peak) in the hiking itinerary is influenced by various factors. It seems that the most important is the ease with which visit to one additional peak can be done (the proximity of other peaks, existence of multiple trails for a combination of various ascents and descents, etc.). In contrast to tourism in general, an obstacle to visiting more than one (hiking) destination could be also the (excessive) effort needed to reach it. This is especially important for one day trips.

Findings presented in the paper show a complex picture of spatial characteristics of recreational use of mountain areas. Even neighbouring mountain summits can - despite their proximity - significantly differ in the origin and direction of visitor flows, their inclusion in various hiking itineraries and other properties. Knowledge of visit characteristics and factors that influence them is not important only for better understanding of this specific type of tourism/recreation but, also in the context of providing appropriate leisure opportunities (leisure as an essential element of the quality of life) as well as in a study of various impacts of tourism and recreation in mountain areas. The paper leaves some questions unanswered. The exact nature and role of some factors, which affect the visits of mountain peaks and its characteristics, remain unclear. Additional research could point out new factors which could not be detected by this research. Taking into account the importance of high mountain areas as a recreation space for Slovene population as well as many tourists the additional, more extensive research would be more than welcome.

(Translated by the author) 